\title{
Endoscopic obturation of esophageal and gastric varices with a cyanoacrylic tissue adhesive
}

\author{
JEAN-PIERRE GOTLIB, MD
}

ABSTRACT: An original method of obturation of esophageal and gastric varices with a cyanoacrylic glue has been used for nine years. This method allows treatment of gastric and very large esophageal varices, which is difficult with common endoscopic sclerotherapy, and makes hemostasis in case of acute bleeding easier. There are few complications, none lethal. Can J Gastroenterol 1990;4(9):637-638

Key Words: Esophageal varices, Gastric varices, Sclerotherapy

\section{Obturation endoscopique des varices oesophagiennes et gastriques à l'aide d'un adhésif tissulaire cyanoacrylique}

RESUME: Une méthode originale d'obturation des varices oesophagiennes et gastriques à l'aide d'une colle cyanoacrylique est utilisée depuis neuf ans. Elle permet de soigner les varices gastriques et les varices oesophagiennes de très grandes dimensions, difficiles à traiter par la sclérothérapie endoscopique habituelle. Elle facilite également l'hémostase en cas d'hémorragie aiguë. Elle entraîne peu de complications et aucune d'elles n'est fatale.

E NDOSCOPIC INJECTION THERAPY was first proposed as a treatment for esophageal varices in 1939 by Crafoord and Fenckner (1). For many years it remained an unpopular and infrequently used mode of therapy. However, dis- appointing experience with portosystemic shunting and other surgical approaches for esophageal varices, in terms of both morbidity and mortality, led to renewed interest in endoscopic sclerotherapy during the 1970s.
Unité de chirurgie hépato-biliaire, Hôpital Paul-Brousse, Villejuif, France

Correspondence and reprints: Dr J-P Gotlib, Consultation d'endoscopie digestive, Unité de chirurgie Hôpato-biliaire, Hôpital Paul-Brousse, 12-14 avenue Paul-Vaillant Couturier, 94800 Villejuif, France
Numerous controlled trials completed during the past five to six years have confirmed its efficacy in both reducing rebleeding and increasing survival of patients who have previously bled from esophageal varices.

The authors decided, in 1980, to try an original method using a cyanoacrylic glue make hemostasis easier (in case of acute bleeding) and to reduce bleeding caused by the injections. This glue had been employed previously for several years by surgeons as a hemostatic agent following resection of parenchymatous organs and by radiologists as an embolization agent. It hardens immediately in contact with blood and so obliterates varices (2-5).

The authors first employed Ethicon Bucrylate (Ethnor) but its production was stopped when it appeared that under certain conditions (high dose intraperitoneal injection in rats) it could cause sarcomas. It was then replaced by n-butyl-2-cyanoacrylate (Histoacryl; Laboratoires Bruneau, Boulogne), which has similar properties. To the author's knowledge, no case suggesting carcinogenicity of butyl-cyanoacrylate in humans has yet been reported, al- 
though this tissue adhesive has been widely used for more than 20 years.

Injection therapy is performed using a common sclerosis needle through a flexible Olympus GIF 1T endoscope: the large channel allows suction even when the needle is introduced. Histoacryl is mixed with an equal quantity of ethiodized oil (Lipiodol: Therapex), and 1 to $4 \mathrm{~mL}$ of this mixture are pushed into the varix with pure Lipiodol. The purpose of the oil is to delay hardening of the glue and to allow radiological control of the cyanoacrylate casts in the variceal columns later, if necessary. A small leakage of glue happens very often. Damage to the scope by the glue can in most cases be avoided if certain precautions are taken. The sheath and working channel must be lubricated with silicone oil. Suction must be interrupted during injection and a few seconds after. If the leakage is too great, visibility may become insufficient; further injections should be performed in a second session. Post injection tamponade is not necessary using this technique.

All varices are treated in one or two sessions. After one or more weeks, the cyanoacrylate is gradually expelled from the varix into the digestive lumen. The first control endoscopy is performed one week after injection. Thereafter, repeat endoscopies are performed at one, three and six month intervals, and then every six months. Reappearance of varices during followup is treated by repeat injections according to the same protocol. The process of expulsion of cyanoacrylate casts is monitored endoscopically and, if necessary, by radiological control.

During the five year period between January 1, 1981 and December 31, 1985, 317 patients with esophageal varices were treated by endoscopic injection therapy at l'Hôpital Paul Brousse in Villejuif, France. One hundred and twenty patients were treated at the time of acute variceal hemorrhage (within 10 days of a variceal bleed); five were treated prophylactically (ie, had never bled); $10 \mathrm{had}$ an etiology of portal hypertension other than cirrhosis; 13 had cirrhosis with coexisting hepatocellular carcinoma; and 14 had endoscopic injection therapy as an adjunct to another form of treatment. The remaining 155 patients were entered in a prospective study of elective endoscopic injection therapy in cirrhotic patients with esophageal varices which had bled more than 10 days previously.

Thirty-three per cent of these patients were in Child group A (6); $45 \%$ group B; and $22 \%$ group C. Fortyone per cent had recurrent hemorrhage from esophageal varices.

Among the patients treated at the time of acute variceal hemorrhage, $16 \%$ were in group $\mathrm{A}, 30 \%$ group $\mathrm{B}$ and $54 \%$ group C. Twenty per cent of patients had recurrent hemorrhage from esophageal varices during the first month following endoscopic injection therapy. Sixteen per cent died in the first month from variceal hemorrhage or problems associated with it (hepatic, renal or respiratory failure).

No patient died or required surgery as a result of a complication of endoscopic injection therapy, and a very small number suffered significant complications following injection: transient esophageal stenosis which generally disappeared spontaneously or after simple passage of an endoscope; transient dysphagia without stenosis; proven bacteremia (two cases); and transient unexplained pyrexia. No fibrous esophageal strictures, perforation or pneumothorax was encountered. Luckily, the seldom described lung or brain migrations, probably related to abnormal anatomic configuration, were not seen.

In conclusion, endoscopic glue obliteration is a satisfactory method for treatment of esophageal and gastric varices. The technique is both simple and safe. The rebleeding rate is too high mainly because recurrence of varices often occurs in patients with active hepatitis, persistent alcohol in take or hepatocellular carcinoma. For this reason the author now combines obturation and sclerosis: after the glue is expelled (usually one month), four submucosal injections of 3 to $5 \mathrm{~mL}$ of $1 \%$ polidocanol are made around the cardia to prevent variceal recurrence $(7,8)$. Polidocanol is also used for sclerosis of small varices. However, in the author's experience under some conditions (emergency hemostasis large esophageal varices), obturation seems to be the best treatment. For gastric varices, it is the only nonsurgical solution (9).

\section{REFERENCES}

1. Crafoord C, Fenckner C. New surgical treatment of variceal veins of oesophagus. Acta Otorhinolaryngol (Stockh) 1939;27:422-9.

2. Gotlib JP, Houssin D, Demma I, Bismuth H. Traitement endoscopique des varices oesophagiennes du cirrhotique: Une série continue de 50 malades. Gastroentérol Clin Biol 1983;7:198.

3. Gotlib JP, Demma I, Fonsecca A. Résultats à 1 an du traitement endas. copique électif des hémorragies par rup ture de varices oesophagiennes chez le cirrhotique. Gastroentérol Clin Biol 1984;8:133A.

4. Gotlib JP, Zimmerman P. Une nouvelle technique de traitement en. doscopique des varices oesophagiennes: L'obturation. Endosc Dig 1984;7:10-2.

5. Ramond MJ, Valla D, Gotlib JP. Obturation endoscopique des varices oeso-gastriques par le Bucrylate. I Etude clinique de 49 malades. Gastroentérol Clin Biol 1986;10:575-9.

6. Pugh RNH, et al. Transsection of the oesophagus for bleeding oesophageal varices. Br J Surg 1973;60:646-9.

7. Soehendra N, Nam VC, Grimm H. Endoscopic obliteration of large oesophagogastric varices with Bucty. late. Endoscopy 1986;18:25.

8. Soehendra N, Grimm H, Nam VC. $\mathrm{N}$-butyl-2-cyanoacrylate: A supplement to endoscopic sclerotherapy. Endoscopy 1987:19:221-4.

9. Ramond MJ, Valla D, Mosnier JF. Successful endoscopic obturation of gastric varices with butyl cyanoacty. late. Hepatology 1989;10:488-93. 


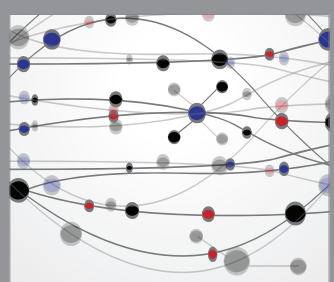

The Scientific World Journal
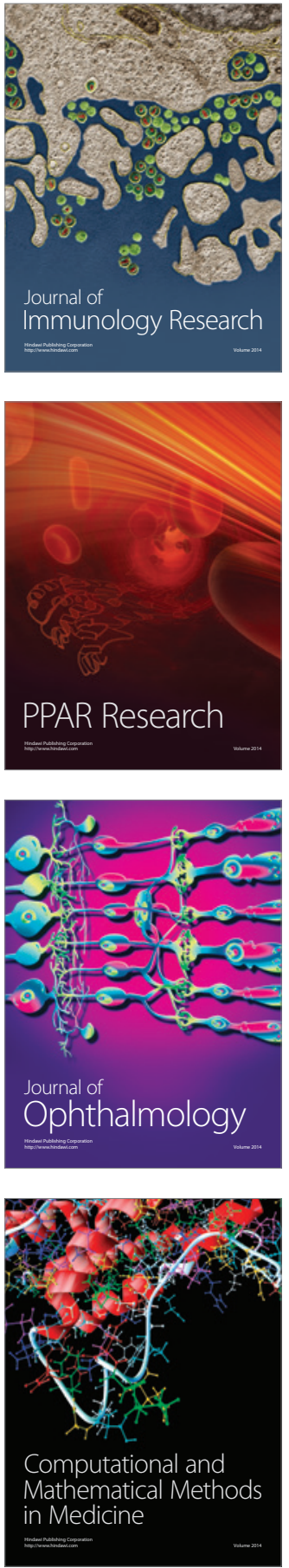

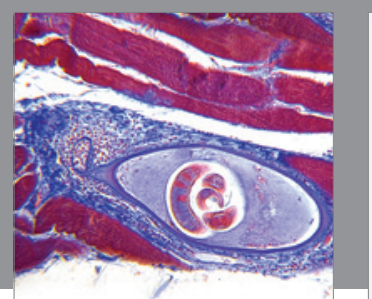

Gastroenterology Research and Practice

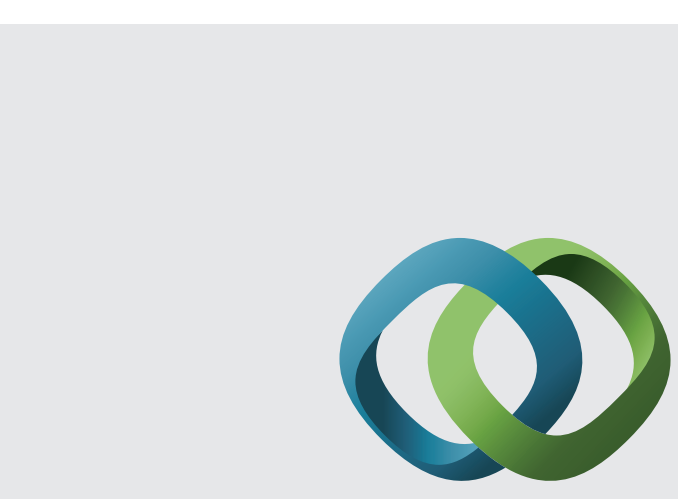

\section{Hindawi}

Submit your manuscripts at

http://www.hindawi.com
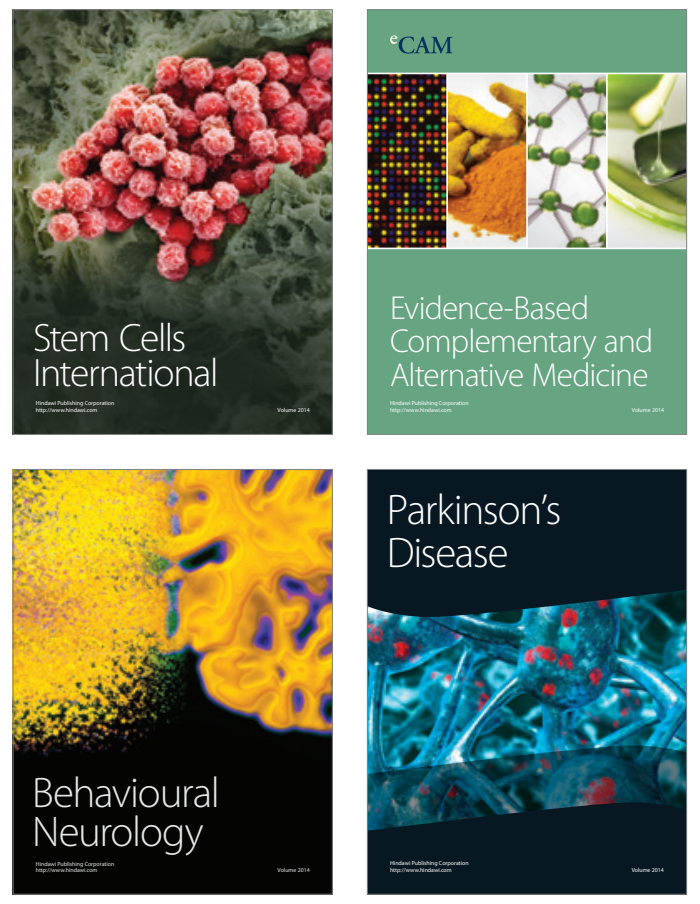
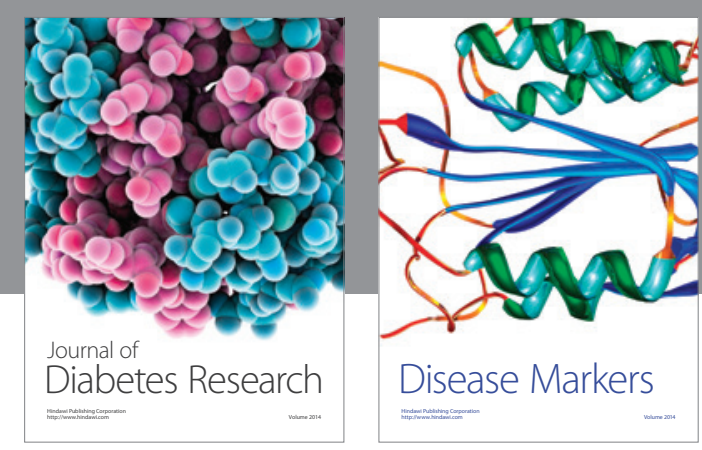

Disease Markers
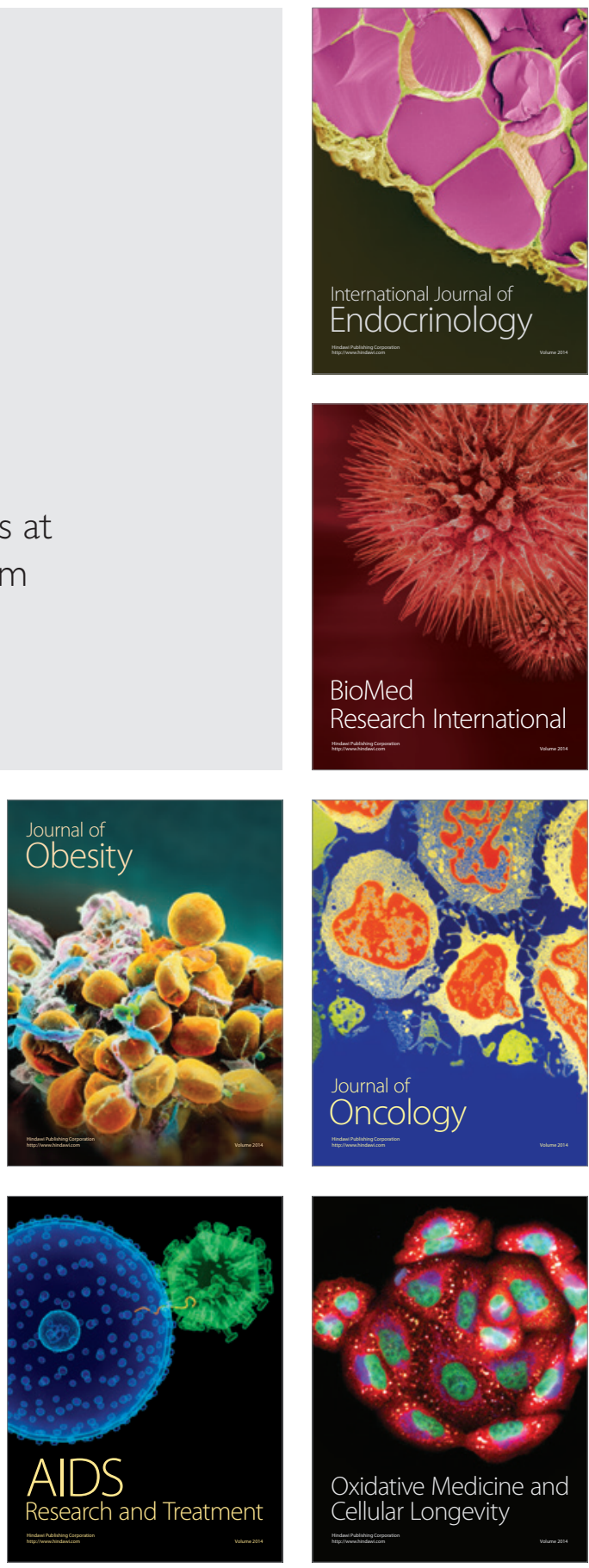